DOI: $10.20472 /$ IAC.2019.048.006

SUTANA BOONLUA

Mahasarakham Business School, Mahasarakham University, Thailand

\title{
GUIDELINES FOR LEARNING AND DEVELOPMENT OF THE LOGISTICS COMPANIES IN THAILAND
}

\begin{abstract}
:
The key question is what are the guidelines for leaning and development of logistics companies in Thailand for competitive advantages? And the main objective is to examine the guidelines for leaning and development of logistics companies in Thailand for competitive advantages.There are three theoretical contributions which are (1) strategic competitive advantages, (2) balanced scorecard, and (3) knowledge management. This research used the questionnaire mailing, the surveys completed and returned of 84 respondents. The key informants were the managing directors or managers of each logistics companies in Thailand which registered as members of the Thai International Freight Forwarders Association (TIFFA). This empirical research explains concepts associated with how a logistics companies achieve and fulfill their goals and maintain their sustained competitive advantage with greater learning and growth perspective of the companies in a turbulent business environment. The nature of strategic competitive advantages for future research also suggested at the latter.
\end{abstract}

\section{Keywords:}

strategic competitive advantages, balanced scorecard, knowledge management, logistics companies 